\title{
A Development Policy of Networking-Based Creative Marine Small and Medium Enterprises as a Solution for Poverty Alleviation in Indonesia
}

\author{
Slamet Rosyadi ${ }^{1}$, Elpeni Fitrah $^{1}$, Ayusia Sabhita Kusuma ${ }^{1}$ \\ ${ }^{1}$ Faculty of Social and Political Sciences, University of Jenderal Soedirman, Indonesia
}

\begin{abstract}
Poverty and environmental degradation are issues that have not been resolved in the coastal communities and regions yet. The various policies and development programs have been implemented to address these two main issues. Nevertheless, the poverty rate of coastal communities remains high. To address the problem of poverty in coastal areas, this study tries to offer a policy solution for SME development based on the creative power of network resources. The concept of creative economy is very relevant because the environment and marine fisheries resources provide potential materials for SMEs to manage. Management of marine resources by combining creativity, innovation, and technology can lead to products that have market competitiveness. To support these efforts, the utilization of network resources can provide synergistic power to improve product quality and competitiveness. These networking resources can come from elements of government, business, civil society, financial institutions, professional institutions, universities, and other social communities. The collaboration of these various network resources can be an effective force in poverty alleviation efforts in coastal areas. Studies have supported that poverty alleviation is not effectively implemented if it does not synergize the bureaucratic, business and community forces. The problem of poverty in coastal areas of a complex character cannot be overcome with a linear approach. Moreover, breakthroughs and innovations need to be done to address the complexity of poverty of coastal communities. To that end, the strength of marine SMEs needs to be integrated with the approach of creative economy and networking so that it becomes a driver of the local economy that serves as a solution for poverty alleviation.
\end{abstract}

\section{Introduction}

Common characteristics found in coastal areas in developing countries are the low level of community welfare and the damaged natural resources environment [1]. Statistical data in Indonesia shows that 32.4 percent of coastal communities are categorized as poor. Even the number of poor people in the fishing community is twice as many as other communities.

\section{Corresponding author: slamet.rosyadi@unsoed.ac.id}

This situation is very paradoxical to see the fishermen's environment that provides a great economic potential for the welfare of fishermen communities.

Some of the causes behind severe poverty rates have been described by many researches. Those causes are such as the lack of access to natural resources, the lack of community participation in policy and program formulation, the lack of human resources, 
the lack of infrastructure and technology, and the lack of capital [1,2,3]. Generally, the underlying causes of poverty found in coastal communities are low education, highly consumptive lifestyles, dependence on coastal resources, minimal business skills, and limited market access [3].

Various development programs and community empowerment, especially from the government budget has been widely allocated to coastal areas. However, the poverty situation in coastal areas has not changed much. Ironically, it is the government's policy which also increases the reproduction of poverty of coastal communities especially the traditional fishermen. In this context, it is necessary for the strength of social networks to be involved in poverty reduction efforts. This paper is intended to provide thoughts on poverty reduction policy strategies with the strength of social networks that juxtaposed with SMEs. To align with the dynamics of the ever-evolving market changes, the creative economy approach needs to be adopted in the development of SMEs. Various researchers have found that the industrial strength of the creative economy has brought significant changes to the local economy [4]. In the context of coastal areas, various potentials of sea and coastal resources should be managed by combining innovation, technology, social capital in the building of strong industrial posture. Thus, efforts to integrate the power of creative economy and social networking become important to be developed for SMEs in coastal areas have the competitiveness to be a solution to poverty alleviation.

\section{Figure 1 Research Method}

To address the problem of poverty in the fishing community, this paper applied the literature study method. Various publications in the form of books, research journals, news and media analysis and statistical reports relevant to the issues are reviewed. Information from the results of the study then aimed to find answers to potential SMEs of creative economy based on network resources as a solution to poverty alleviation.

\section{Figure 2 Results and Discussion}

\subsection{Problem of Policy Institution}

Following institutional theory, this paper argues that policy structures (institutions) for poverty alleviation in coastal community create interaction among coastal communities and government or other stakeholders in making decision and forming judgements about 'good' policy [5].

The issue of poverty alleviation has become a major part of the government's responsibility. Central and local governments have managed various poverty reduction programs with an integrated approach. Efforts to reduce poverty in government perspectives are translated into social assistance programs, community empowerment programs, and empowerment of small businesses. To ensure the effectiveness of this poverty alleviation program, Presidential Regulation no. 15/2010 on the acceleration of poverty alleviation and institutional of National Team of Acceleration of Poverty Alleviation (TNPP2K). With this institution is expected to create coordination across sectors and cross-stakeholders at the center and regional levels in an effort to accelerate poverty reduction (source: http://www.tnp2k.go.id).

With many stakeholders involved in poverty alleviation programs, cross-sector and agency coordination is a formidable challenge. The failure of various policy implementations derived from weak coordination. The more actors and institutions involved, the more difficult it is to bring together diverse interests. As a result, poverty 
reduction programs aimed at fishing communities are also ineffective in improving their welfare.

Statistics show that the number of poor people with spending size decreased by 1.19 million people or 10.12 percent. Thus, the number of poor people who originally reached 27.77 million people in 2017 was reduced to 26.58 million people [13]. Although the number of poor people declines, the severity of poverty is still high. BPS reports that the index of poverty depth and poverty severity index has increased from March to September 2017. In March 2017, the numbers ranged from 1.74 and 0.44 . However, in September 2017 increased to 1.83 and 0.44 (http://www.liputan6.com). Increasing the severity and depth of poverty indicates that the poor are getting harder to get out of economic trouble. Moreover, the poverty found in coastal areas shows that the level of expenditure is very high compared to the mainland. Thus, the poverty rate in coastal areas can reach twice as much than in other areas.

The failures of poverty alleviation policies in the coastal areas are due to weak community capacity in decision-making, lack of community participation in policy and program formulation [1], and lack of government agenda on the issues of empowerment in macro policy [6]. Thus, it is not surprising to find out that the prevention of poverty in the coastal areas is much more difficult than in the mainland. Consequently, the government must spend a much larger state budget to address the problem of poverty in coastal areas. The weak design of poverty alleviation policy especially for coastal area can also be seen from the relation that formed among fishermen community. In his study, Ferry Joko Juliantono [7] found that public policy formulations in coastal areas ignored the dichotomous reality between traditional fishermen and modern fishermen. One example of the case is Ministerial Regulation no. 2 / Permen-KP / 2015 on the prohibition of the use of trawl fishing gear and trawl net. Traditional fishermen oppose the ban because they are relying on the two fishing gear. Ironically, the government does not provide short-term policy solutions to anticipate the impact of ministerial regulations on traditional fishermen whose numbers are larger than modern fishermen. As a result, most traditional fishermen are unable to catch fish and become more entangled with debt to the moneylenders. The poverty of fishermen becomes increasingly difficult to overcome. Thus, policy design in this context is at the root of the problem of poverty.

\subsection{SMEs of Creative Economy in Coastal Area}

In quantity, amount of SME's in Indonesia develop significantly. Until 2017, the number of SME's are 60 million, it increases 3,1\% from the previous year. The contribution of SME's to the national economy is also quite large at around $61.41 \%$ of Gross Domestic Product (GDP) (https://nasional.sindonews.com/read/1278750/18/resolusiumkm-indonesia-1517531360). Furthermore, employment provided by SME's can accommodate approximately 57.8 million people[8]. Those data show the important role of SME's in local and national development. The development of creative economy sector as a part of SME's also shows good performance. Creative economy sector contributes for about 7,38 \% to national economy, and Gross Domestic Product (GDP) of creative economy sector shows 4,38 \% in 2015 [9]. Creative industry in Indonesia posted strong and positive growth in the last three years which is contributing 852 IDR to GDP in 2015; 922,58 trillion in GDP in 2016; and 999.4 trillion IDR to GDP in 2017.

Creative economy approach for SME's development is expected to increase the added value of the products. Value added will increase if SME's have the enhancement of knowledge, creativity and technology. In the era of openness market competition, it demands the products that offer value added and benefit which are not provided by the previous market. There are 16 creative economy sectors; 1. Advertising, 2. Fine arts, 3. 
Crafts, 4. Fashion, 5. Films, Animations and Videos, 6. Photography, 7. Interior Design, 8. Performing Art, 9. Architecture, 10. Applications and Game Developer, 11. Publishing, 12. Television and radio, 13. Research and Developments, 14. Culinary, 15. Visual Communication Design, 16. Product Design [9]

Development of SME's creative economy in the coastal areas also has excellent prospects. Employment opportunities will be open to coastal communities including fishermen. The coastal region actually holds enormous creative economic potentials to develop. Not only fisheries products, but coastal environment has a range of natural resources, which include coral reefs, sea grass, mangrove and also coastal tourism services. Creative economy sectors that can be develop in coastal areas are seafood culinary; craft from sea shells; film, animations and videos; music; performing arts; research and developments; etc. Those natural resources will provide some potential income to the community if it be managed properly.

The potentials of creative industries in coastal area will have a great effect if the community and fishermen strongly become the main actor in the management of creative economy. In the coastal areas, all the community (fishermen and the villagers) can take advantage of BUMDES (Badan Usaha Milik Desa/ village-owned enterprises) to manage the potential of coastal nature resources collaboratively with local government. BUMDES provides funds and capital to enhance village's potentials economy creative sectors including in coastal areas. Fishermen empowerment also strongly needed in entrepreneurship and human development programs to strengthening institutional management of SME's and creative industry sectors. Moreover, the empowerment of the community will support undeveloped coastal areas to be expanded through a sustainability process in terms of its utilization to nature preservation and tourist destinations. On the other hand, the development of the tourism sector in coastal areas will increase community income of creative products such as souvenirs or culinary. This kind of activities will create the coastal economy into more dynamic progress. Fishermen will not only depend on fishing activity on the high seas. Another impact is coastal ecology will be further preserved and maintained from destructive activities.

\subsection{The role of social network}

The use of communication and information technology is needed to expand new services and products to potential customers. SME's including creative industries take a huge advantage in the social network era [14]. Technological advances allow SMEs and creative industries to intercept communication with various parties through Facebook, Twitter, Instagram and Wwhatsapp. The study by Franco [10] shows that social networking utilization such as Facebook is related to efforts to reduce costs, improve communication and maintain customer satisfaction.

Social networks help SME's and creative industries to increase innovation and knowledge. Social networks provide important information from external parties such as customers or community institutions. This information is a knowledge acquired by SMEs and creative industries to increase their capacity in production and product management so that the quality of products will be well maintained. Similarly, consumer loyalty can also be maintained with the existence of online social networking.

The use of online social networking media in Indonesia itself according to Report Tetra Pak Index 2017 has reached 132 million users. Interestingly, 40 percent of total online media users are categorized as online media enthusiasts (https://inet.detik.com/cyberlife/d-3659956/132-juta-pengguna-internet-indonesia-40-

penggila-medsos). The increase of sophisticated mobile phone technology, lead to the use of social networks as a means to exchange information; marketing ads and online services; 
and also to coordinate some various activities. SMEs and creative economy sectors can take advantage of the benefits of social media applications to capture cooperation with various parties and market, so their products and services can expand on a wider scale.

\section{Figure 3 Policy Implication}

Future poverty reduction strategies need to consider the development of SMEs based on social networks. As can be seen in Figure 1, social networks can provide resources such as knowledge, experience, and expertise. These resources are needed by SMEs in creative economy to increase value added, expertise and market access so that SMEs have the required competitiveness.

The development of SMEs provides alternative employment opportunities for fishing families. The dependence of fishermen on fishing activities has caused the fishermen not to have time to develop other businesses. The presence of SMEs can provide access to family members of fishermen to process marine resource products. This productive activity provides an alternative source of income for the fishermen's economy. In the long term, SMEs that continue to grow with the power of social networking can improve the creativity of various processed products and will ultimately provide a long-term impact of improving the welfare of coastal communities.

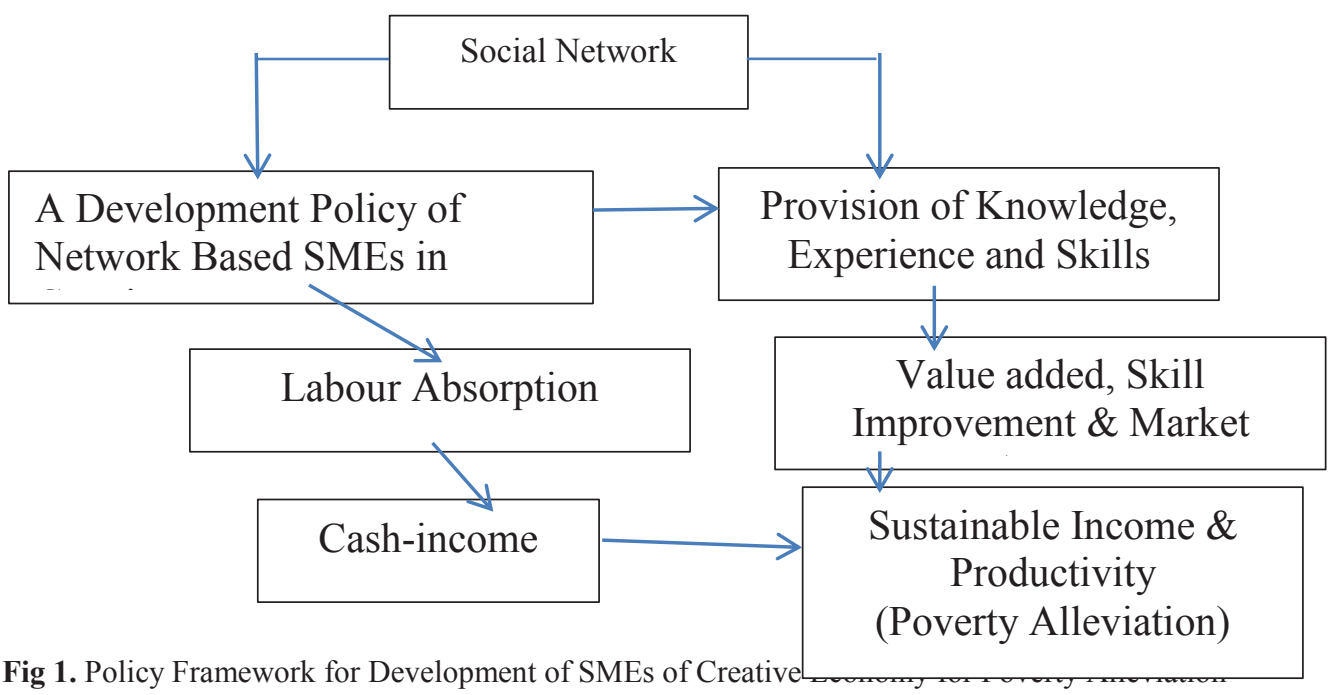


To create a conducive climate for the development of SMEs creative economy requires great support and political commitment from the government $[11,12]$. The case of the ban on the use of traditional fishing gear in the absence of short-term solutions is an important lesson for policymakers. Governments should consider appropriate institutional designs with the sociological context of the group of policy recipients. Therefore, the government should build intensive public communications with recipient groups so that great support from the public will be built on formulation of public policy.

\section{Figure 4 Conclusion}

Poverty alleviation for coastal communities requires a new approach. Various program interventions and public policies that have been implemented have proven to have insignificant effect on changes in the socio-economic conditions of better fishermen communities. Poverty and environmental degradation continue to occur in coastal areas. The failure of poverty reduction programs and policies is caused by a less comprehensive policy format in integrating social, economic and cultural issues of coastal communities.

The dependence of coastal communities on external program intervention is increasing. External parties, especially the government, are considered less able to establish effective public communications with coastal communities. As a result, data and information on the roots and poverty solutions received by the government are inconsistent with the actual conditions and needs of the poor in coastal areas. Various program interventions allocated to empower the community create the reproduction of community dependency.

The socio-economic approach through creative economy development with the base of SMEs become an alternative policy solution in poverty eradication of fisherman society. SMEs of creative economy is selected with the consideration that to grow the economic independence of coastal communities needs a strong and creative socio-economic institution. The creative economy model offers solutions that match new challenges at the local and global levels. To cultivate creativity and expertise in coastal communities requires the power of social networks involving elements of government, business, civil society, and college. With the exchange that involves social networking, the socio-economic empowerment process of the fishermen community will develop sustainably and adaptively with the dynamics of environmental change.

\section{References}

1 Rosyadi, S., \& Tobirin. (2010). Perumusan kebijakan publik dalam menggali akar kemiskinan. Jurnal Ilmu Administrasi Negara 10 (2), 114-125.

2 Islam, M.M. (2010). Poverty in small-scale fishing communities in Bangladesh: Contexts and responses. Dissertation. Bremen International Graduate School for Marine Sciences, Germany.

3 Muthalib, A.A., Nuryadi, A.M., \& Almana. L.O. (2015). Poverty alleviation through community empowerment based farming ponds in coastal areas Southeast Sulawesi. The International Journal of Engineering and Sciences (IJES), 4 (10), 32-40.

4 Boccella, N., \& Salerno, I. (2016). Creative Economy, Cultural Industries and Local Development. Procedia - Social and Behavioral Sciences 223, 291 - 296.

5 Peters, B.G. (2010). Institutional Theory: Problems and Prospects. Political Science Series 69. Institute for Advanced Studies, Vienna.

6 Kurniasari, N., \& Reswati, E. (2011). Memaknai Program Pemberdayaan Ekonomi Masyarakat Pesisir. Buletin Sosek Kelautan dan Perikanan 6 (1), 7-13. 
7 Juliantono, F.J. (2015). Dinamika Relasi dan Struktur dalam Reproduksi Kemiskinan Masyarakat Nelayan: Studi atas Masyarakat Nelayan di Desa Teluk, Labuan, Banten. Dissertation. FISIP UI, Depok.

8 Putra, A.H. (2016). Peran UMKM dalam Pembangunan dan Kesejahteraan Masyarakat Kabupaten Blora. Jurnal Analisa Sosiologi 5 (2), 40-51.

9 Profil Usaha/Perusahaan 16 Subsektor Ekonomi Kreatif (2017). Retrieved May 3, 2018 from http://www.bekraf.go.id/berita/page/17/profil-usahaperusahaan-16-subsektorekonomi-kreatif

10 Mário Franco, Heiko Haase, Ana Pereira, (2016) "Empirical study about the role of social networks in SME performance", Journal of Systems and Information Technology, Vol. 18 Issue: 4, pp.383-403, https://doi.org/10.1108/JSIT-06-2016-0036

11 Govori, A. (2013). Factors affecting the growth and development of SMEs: Experinces from Kosovo. Mediterranean Journal of Social Sciences 4 (9), 701-708.

12 Lee, J.H., So, Sohn, S.Y., \& Ju, Y.H. (2011). How effective is Government Support for Korean Women Enterprenuers in Small and Medium Enterprises. Journal of Small Business Management 49 (4), 599-616.

13 BPS: Tingkat Kemiskinan di RI Makin Parah Selama 6 Bulan. Retreived from https://www.liputan6.com/ bisnis/ read/3025513/bps-tingkat-kemiskinan-di-ri-makinparah-selama-6-bulan

14 Kautsarina. (2013). Electronic marketing through social media (Survey on businessperson of SME in Jambi and Bengkulu). Jurnal Studi Komunikasi dan Media 17 (2), 135-147. 